\title{
SARS-CoV-2 Vaccines: Safety and Immunogenicity in Solid Organ Transplant Recipients and Strategies for Improving Vaccine Responses
}

\author{
Ayelet Grupper $^{1}$ (D) Helena Katchman ${ }^{1}$
}

Accepted: 27 December 2021 / Published online: 22 January 2022

(c) The Author(s), under exclusive licence to Springer Nature Switzerland AG 2022

\begin{abstract}
Purpose of Review While solid organ transplant (SOT) recipients are at the highest risk for severe complications and increased mortality from COVID19 disease, their vaccination against SARS-CoV-2 remains challenging due to fear of immune-mediated adverse events and suboptimal immune response. Our current review is aimed to summarize current knowledge about the safety and efficacy of SARS-CoV-2 vaccines, describe factors that are correlated with immune response, and discuss strategies to improve vaccine immunogenicity in SOT recipients.

Recent Findings SARS-CoV-2 vaccines are safe in SOT recipients and not related to rejection or other major adverse events. The immune response to two doses of vaccine is suboptimal and correlated to age and magnitude of immunosuppression. Administration of a third vaccine dose brings to significant amplification of immune response.

Summary This review strengthens the existing recommendation of vaccination by three doses of vaccine in all SOT recipients and completion of vaccination before transplantation if possible.
\end{abstract}

Keywords COVID-19 in transplant recipients - SARS-CoV-2 vaccine - Immunosuppression and vaccine - Immune response to the vaccine in transplant recipients

\section{Introduction}

Severe acute respiratory syndrome coronavirus 2 (SARS$\mathrm{CoV}-2$ ) infection and the resulting disease, coronavirus disease 2019 (COVID-19), have affected millions of persons worldwide. COVID-19 in solid organ transplant (SOT) recipients is associated with increased morbidity and mortality due to comorbidities and immunosuppression state [1-4].

Nair et al. [5] showed a $30 \%$ increased risk of ventilation or death due to COVID-19 in SOT recipients compared with matched controls, and although symptoms of COVID19 disease are generally similar to those in non-transplant patients [6,7], rates of COVID-19-related hospitalizations

This article is part of the Topical Collection on COVID-19 and Transplantation

Ayelet Grupper

ayeletg@tlvmc.gov.il

1 Organ Transplantation Unit, Tel-Aviv Medical Center Tel-Aviv, Israel and Sackler Faculty of Medicine, Tel-Aviv University, Tel-Aviv, Israel in SOT recipients are higher than the general population [6-8].

In addition, immunocompromised patients who do not mount a strong immune response against SARS-CoV-2 are likely to shed the virus for a longer time and be a source of continued unintended exposure to others [9-11], as well as a potential source of new variants [9].

Vaccines to prevent SARS-CoV-2 infection are considered the most promising approach for controlling the pandemic and are being vigorously pursued. Based on data from other vaccinations, the immune response of solid organ recipients to vaccination may be blunted [12-14], and an adequate vaccine response cannot be assumed.

All transplant recipients are eligible for vaccination unless contraindicated from other reasons. Although the immunogenicity and efficacy of COVID-19 vaccines are uncertain in solid organ transplant recipients [15], the potential for benefit from vaccination likely outweighs this uncertainty.

In this review, we aimed to expand the knowledge and understanding and present an overview of the safety and immunogenicity of the SARS-CoV-2 vaccine in solid organ transplant recipients. 


\section{Safety}

Although there are clear evidence of immune activation caused by SARS-CoV-2, based on large observational cohort studies of transplant patients with COVID-19, there has not yet been detected any correlation of SARS-CoV-2 infection with subsequent rejection [15]. Vaccines could induce alloimmunity by triggering an immune response that is cross-reactive with the allograft, by stimulating previously alloreactive immune cells, or through the nonspecific stimulatory effects of adjuvants that could lead to de novo alloimmunity.

While there is a theoretical concern that vaccination may trigger organ rejection [16-19], or production of de novo anti-donor-specific antibody (DSA) [19-21], also reported for SARS-CoV-2 vaccine [22, 23], numerous studies of some common vaccines have shown no casual association between the two [24-29].

Similar to that, mRNA SARS-Co-2 vaccines in SOT recipients were not significantly related to rejection events in most studies (Table 1).

In one study [30], the authors quote a sixfold higher incidence of rejection in third-dose versus second-dose recipients, based on only one case of rejection per group and the putative mechanism is unclear.

Taking into consideration high SARS-CoV-2 vaccine effectiveness and severe clinical spectrum of COVID-19 disease, these rare cases of rejection did not provide any basis to withholding vaccination in SOT recipients.

In immunocompetent individuals, mRNA SARS-CoV-2 vaccines, similar to other common vaccines, are noted to cause mild-to-moderate side effects, including local pain, headaches, and fatigue [31], with the only rare occurrence of major adverse events [32,33]. Among transplant recipients, SARs-CoV-2 vaccines were not associated with any unexpected short-term local and systemic side effects (Table 1).

\section{Immune Response and Efficacy of Two Doses of Vaccine}

Data regarding immune response to SARS-CoV-2 vaccines have been exponentially accumulating over the last several months.

Some of the recent publications on this topic are summarized in Table 1.

These accumulating data consistently demonstrate a suboptimal humoral immune response among transplant recipients following two doses of mRNA SARS-CoV-2. Among kidney and lungs transplant recipients, the majority of patients did not develop an appreciable humoral immune response (seropositivity rates are between 8.2 to $66 \%$ and 10 to $47.4 \%$ for kidney and lung transplant recipients, respectively), while liver and heart recipients had a better response (seropositivity rates between 37.5 to $80 \%$ and 18.2 to $62 \%$ for liver and heart transplant recipients, respectively) (Table 1 ).

In addition, impairments in T-cell response were also described, with a high rate but reduced magnitude of spikespecific $\mathrm{T}$ helper cell response, as well as limited effector

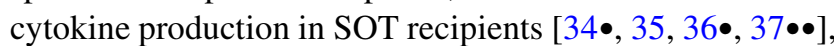
and diminished generation of plasmablasts and memory B cells in response to mRNA vaccine [38]. Although cellular immunity may offset the absence of post-vaccination neutralizing antibodies in SOTRs, among 148 kidney transplant recipients, 35\% developed neither humoral nor cellular responses following vaccination [39•].

The clinical importance of this laboratory finding is supported by growing evidence, suggesting that elapsed time after the vaccination has a major role in breakthrough infections due to wanning immunity and declining of antibody titers [40]. Bergwerk et al. [41] described breakthrough infections with SARS-CoV-2 in a cohort of healthcare workers and a correlation of these infections with the declining of neutralizing antibody titers in the peri-infection period.

Growing bulk of evidence confirm that this observation is true also for immunocompromised patients. Wadei et al. [42] reported on seven SOTRs with undetectable or low titer anti-spike antibodies who developed COVID-19 infection after receiving one or two doses of the SARS-CoV-2 mRNA vaccine. The clinical presentation and course of these patients were comparable to those of SOT recipients who had COVID-19 infection and have not been vaccinated. Qin et al. [43••] analyzed breakthrough SARS-CoV-2 infections in 18,215 fully vaccinated SOTRs at 17 transplant centers and demonstrated an 82-fold higher risk of breakthrough infection and 485-fold higher risks of breakthrough infection associated with hospitalization and death, compared to the general population. Furthermore, while breakthrough COVID-19 is predominantly mild, recent studies show severe and fatal breakthrough infection in transplant recipients with suboptimal humoral responses [43••, 44-49].

\section{Booster}

Observation of the waning immunity demonstrated by decreased antibody levels after two doses of vaccine in the general population [41] as well as breakthrough infections among vaccinated SOT recipients, including severe

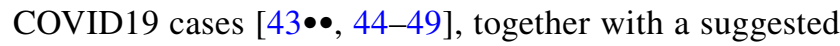
correlation between breakthrough infections and the time that has passed since the second vaccine dose, has led experts including the FDA to recommend the administration 


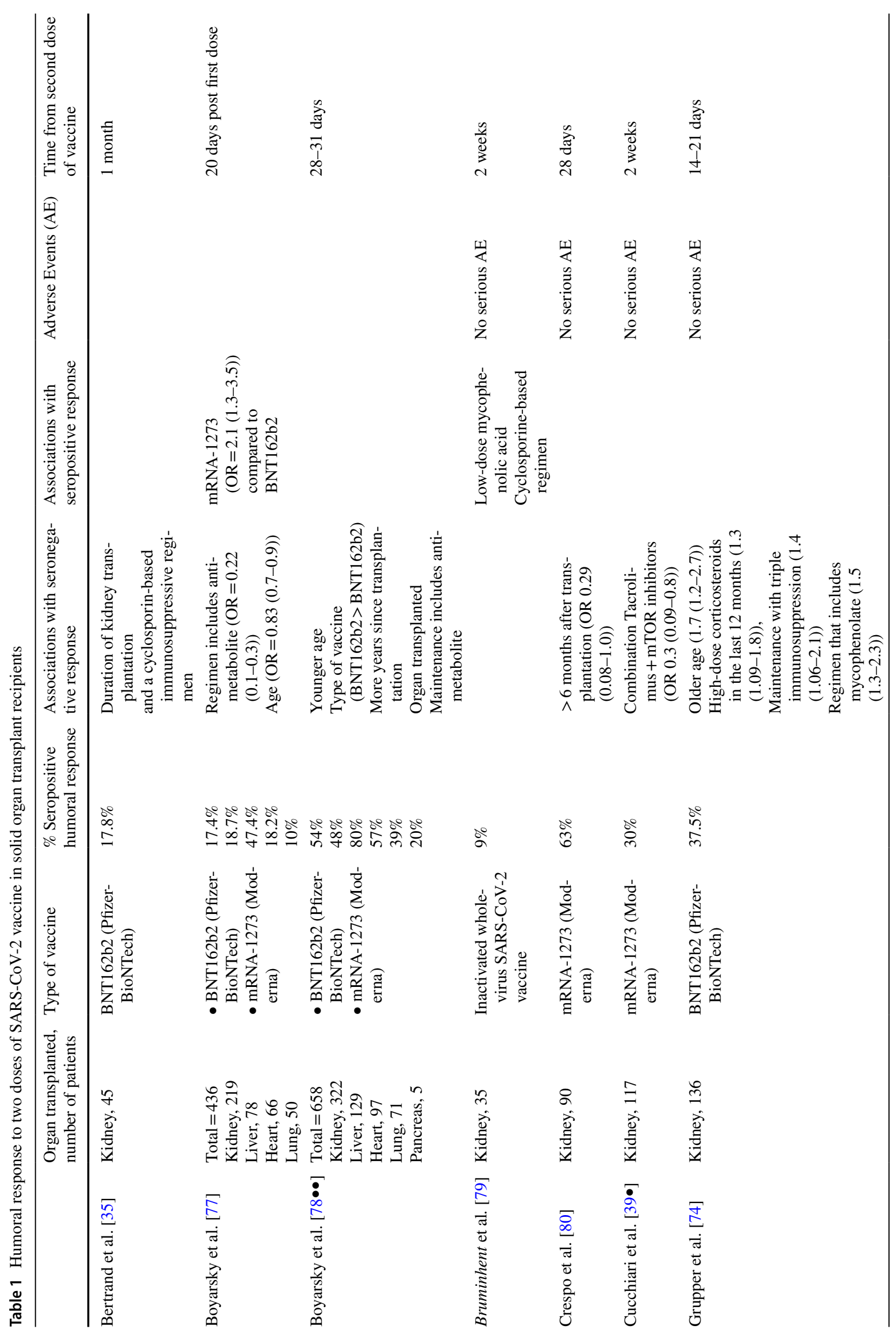




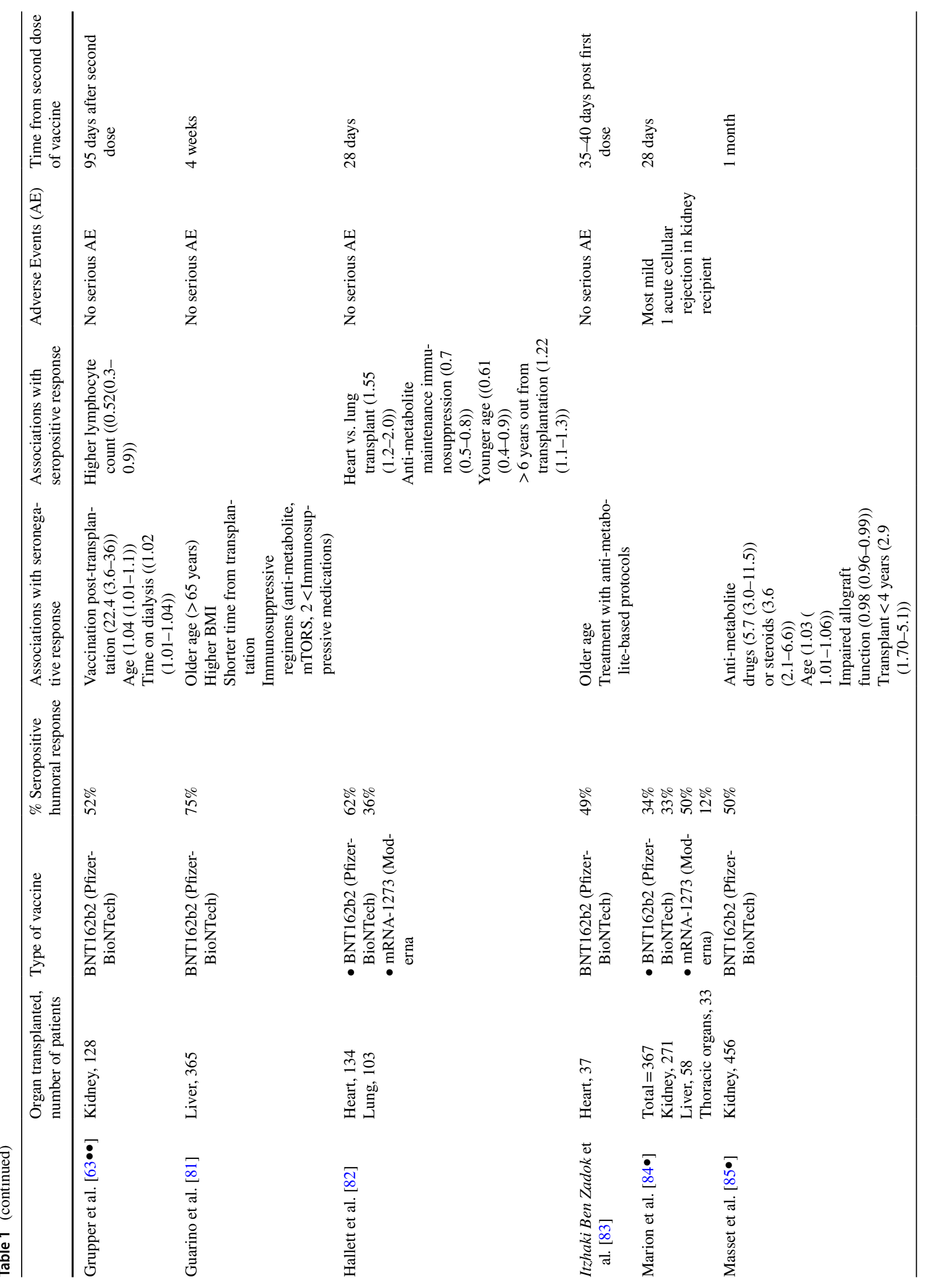




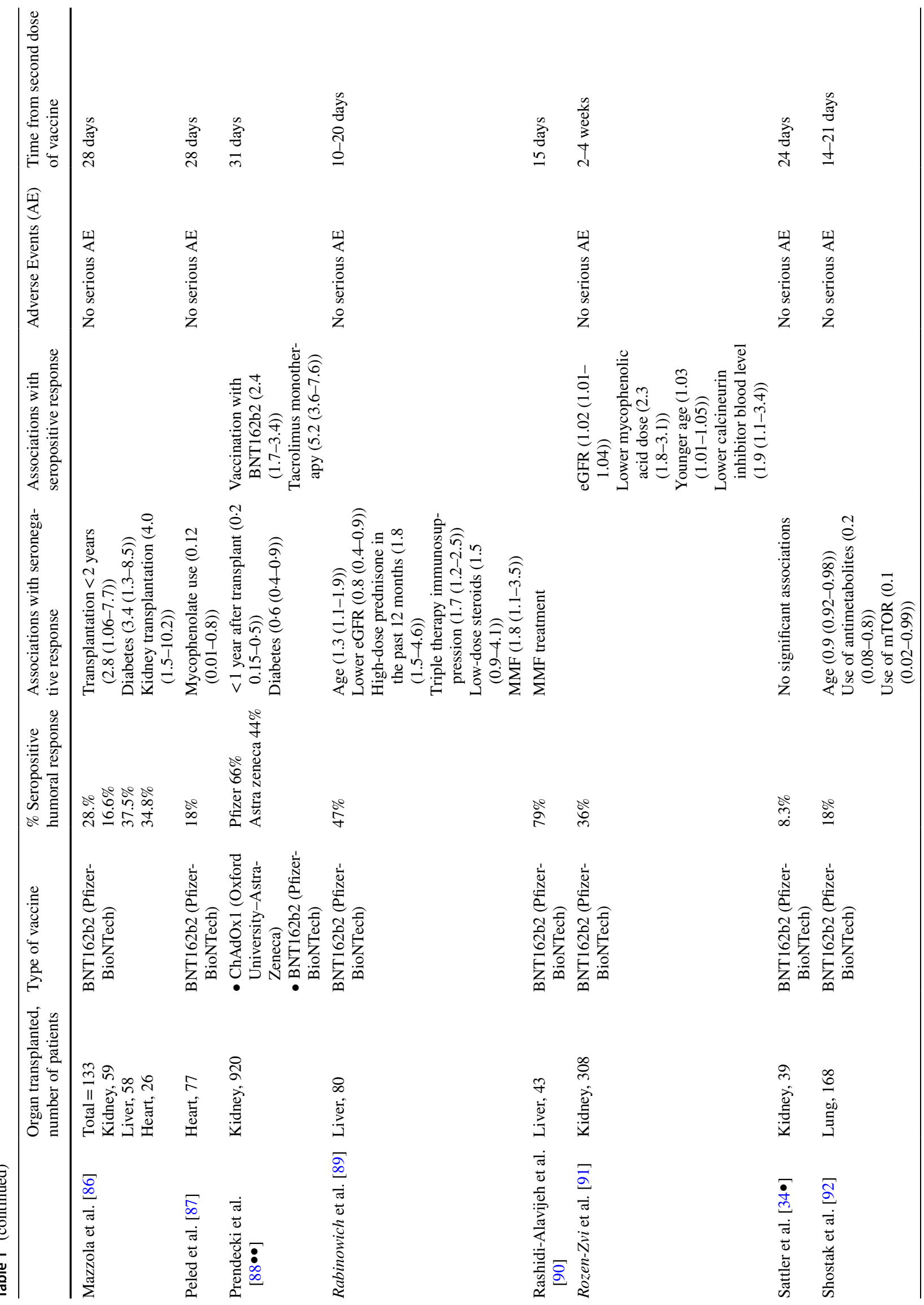




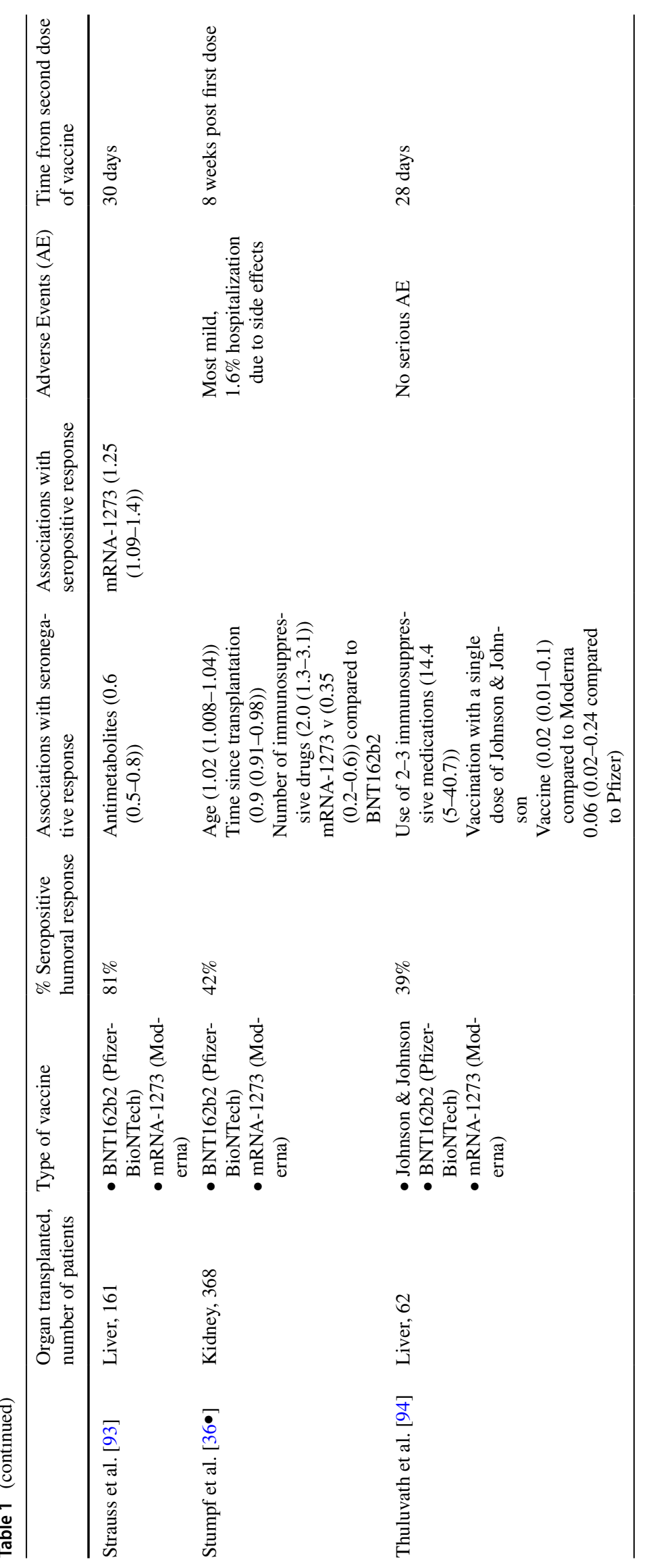


of a booster (third) vaccine dose to immunocompromised individuals, including SOT recipients [50-52].

The CDC recommends that patients who are moderately to severely immunocompromised (including SOT recipients) should receive an additional dose of mRNA COVID-19 vaccine at least 28 days after the second dose [53]. Several countries have made similar recommendations [54-57].

First reports on the administration of a third dose of the mRNA vaccine to SOT recipients have been shown to improve the immune response without causing any shortterm, serious adverse events (Table 2). The third dose of the vaccine in SOT transplant recipients was effectively resulted in increased IgG anti-S levels, including in transplant recipients who were seronegative after two doses.

Hall et al. [58] studied 120 solid organ transplant recipients who had received two doses of an mRNA vaccine and were randomly assigned to either the third dose of mRNA vaccine or saline placebo. A serologic response was present in 55\% of patients in the vaccine group compared with $18 \%$ in the placebo group.

Kamar et al. [59••] reported on SOT recipients (kidney, liver, lung, heart, pancreas) who received three doses of BNT162b2; the prevalence of anti-SARS-CoV-2 antibodies was $0 \%, 4 \%$, and $40 \%$ before the first, second, and third doses, respectively, and $68 \% 4$ weeks after the third dose. Unfortunately, approximately 50 to $70 \%$ of SOTRs who were seronegative after two doses remained seronegative. Adverse effects were similar to those reported after prior doses (Table 2).

Longitudinal follow-up and evaluation of the clinical implication of the third dose in this population are needed to more completely characterize the impact of additional vaccine doses.

\section{Timing}

The ideal timing of vaccination in the post-transplantation setting is not known. In all cases, the likelihood of contracting COVID-19 (based on community prevalence) against the optimal timing with the highest probability of developing a protective immune response to vaccination should be weighted.

ISHLT recommendations are to delay vaccination for at least one month from the time of transplantation and for at least three months after use of T-cell-depleting agents (e.g., anti-thymocyte globulin) or specific B cell-depletion agents (e.g., rituximab) [60].

According to NIH recommendation [61], transplant surgery should be delayed until $\geq 2$ weeks after COVID-19 vaccination. If delayed surgery is not possible, it may be advisable to delay vaccination of transplant recipients for several weeks to months after surgery and the associated use of highly immunosuppressive medications.
The American Society of Transplantation (AST) also recommends vaccinating at least two weeks before transplantation but does not specify whether vaccination should be delayed when T or B cell-depleting agents are used [62].

Our group [63••] has demonstrated a significantly higher rate $(90 \%)$ of positive humoral response to BNT162b2 SARS-CoV-2 vaccine in kidney transplant recipients vaccinated before transplantation, as compared to individuals vaccinated after transplantation (45\%), with appreciable anti-spike antibody response sustained in pre-transplant vaccinated patients even after induction immunosuppression and high-dose steroids treatment. Mean antibody levels in seropositive recipients were similar to healthy controls, suggesting a better chance of responding to the vaccine when administered pre-transplantation.

\section{Parameters Correlated with Immune Response to SARS-CoV-2 Vaccine}

\section{Age}

Advanced age was found to be associated with low antibody response in immunocompetent patients after COVID-19 disease [64], as well as after mRNA SARS CoV-2 vaccination [65]. Older age was a consistent variable related to a poor immune response in recent studies (Table 1), demonstrating that even in immunosuppressed patients, age is an independent predictor of poor immunological response.

\section{Immunosuppression}

The seroresponse to vaccination is related to the net burden of immunosuppression: The greater the degree of immunosuppression, the less likely the patient will respond to immunization. These findings are not only clinically obvious but also supported by previous studies that found a strong correlation of poor seroprotection [21] and increased infection rates [66] with increasing intensity of immunosuppression regimen.

The influence of different immunosuppressive regimens on vaccination response was studied in previous years. A number of studies evaluated response rates to influenza and pneumococcal vaccination in patients receiving glucocorticoids. While the immune response was preserved, although mildly reduced, in most patients on a chronic low dose of glucocorticoids [67-69], the response was inadequate in patients on high dose [70].

Additional studies demonstrated a dose-related correlation of MMF to decreased influenza and cholera vaccine responsiveness in renal transplant subjects [71-73].

Several studies on SOT recipients in mRNA SARS CoV-2 vaccination demonstrate concordant results with significant 


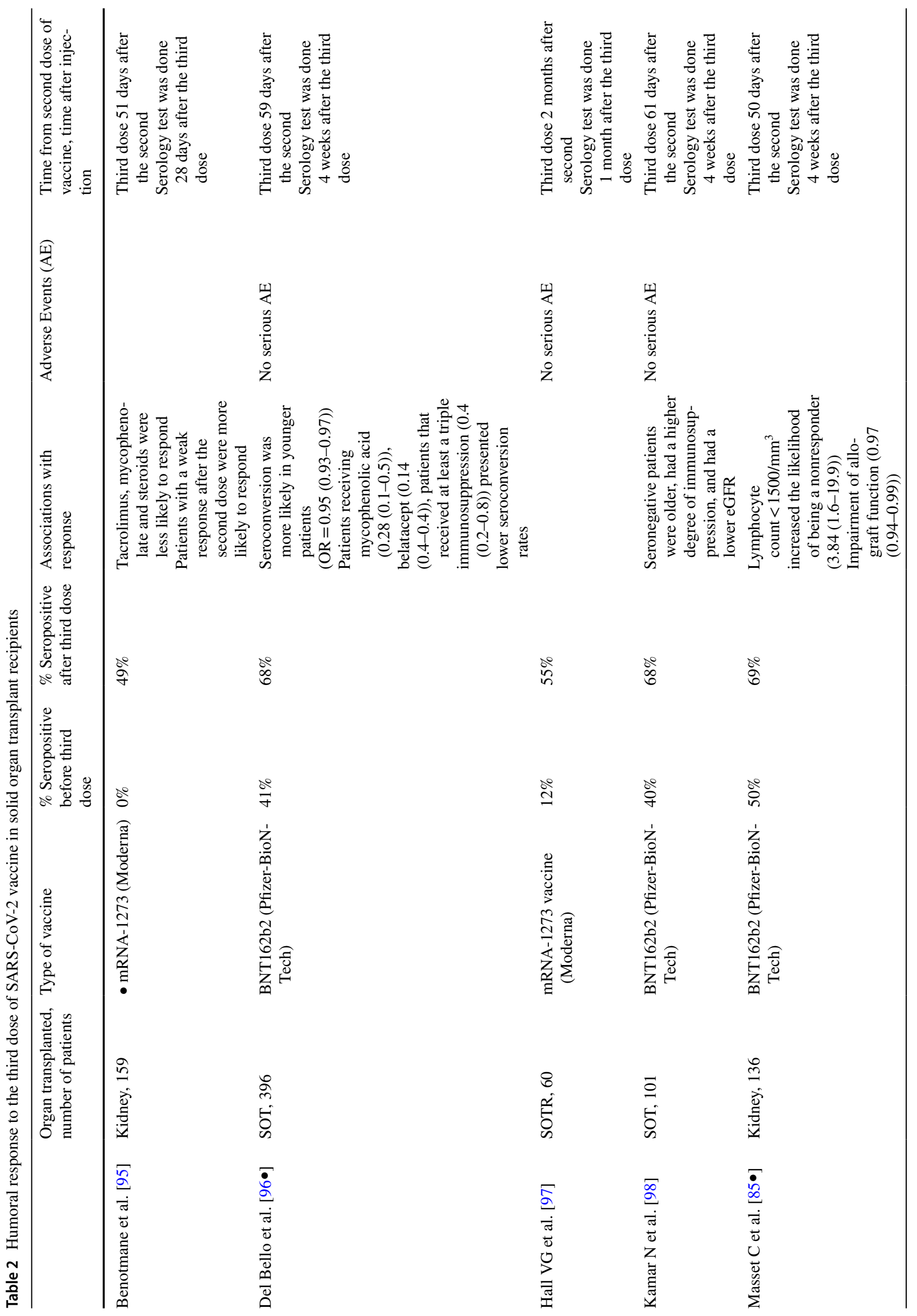


reduction of immune response with anti-metabolite medication, high-dose steroid treatment, or number of chronic immunosuppressive medications (Table 1).

For example, Grupper et al. [74] showed a decrease of $40 \%$ in humoral response for kidney transplant recipients on triple vs. double immunosuppressive medications with the significant negative influence of MMF and high-dose steroids.

\section{How to Enhance the Immune Response to Vaccination}

One possible approach to overcome the low response rate in SOTRs is to choose optimal timing for vaccination, with accumulating evidence of the advantage of pre-transplant vaccination of transplant candidates. After the transplantation, the decision of optimal vaccination timing is more challenging and should take into consideration epidemiological data of the danger of SARs-Cov-2 contraction versus pursuit to delay vaccination at least 1 to 3 months after transplantation considering a decreased immune response to the vaccine during this period (Table 1).

While multiple studies are concordant in the conclusions about the negative influence of immunosuppression (especially MMF and high-dose glucocorticoids) on the vaccination success, there are insufficient data to guide modifications of immunosuppression in anticipation of, or preparation for, vaccination, and society guidelines do not recommend routine modification of immunosuppression [75].

The introduction of a third (booster) dose is currently the best way to increase the immune response to the SARsCov-2 vaccine, and we have sufficient evidence to recommend it in SOT recipients. The longevity of this immune response should be evaluated and may guide us in the decision about the need for additional boosters in the future.

Promising results from the very recent study that used switching to a different vaccine platform in non-responders (e.g., viral vector-based vaccination after failure to achieve a response after mRNA vaccination) propose an additional useful strategy [76].

\section{Conclusion}

Accumulating data about SARA-CoV-2 vaccination in SOT recipients repeatedly confirm the high safety profile of mRNA vaccines. Reduced immunogenicity of the vaccine in SOT recipients is correlated mainly with high immunosuppression burden (and proximity to transplant surgery) and older age. While additional long-term studies are needed to evaluate the possible strategies to increase vaccine-induced protection in SOT recipients, this review strengthens the existing recommendation of vaccination by three doses of 
vaccine in all SOT recipients and completion of vaccination before transplantation if possible. In the meantime, transplant recipients should be advised to continue other protective measures regardless of the number of vaccine doses received.

\section{Declarations}

Ethics Approval and Consent to Participate This article does not contain any studies with human or animal subjects performed by any of the authors.

Conflict of Interest The authors declare no competing interests.

\section{References}

Papers of particular interest, published recently, have been highlighted as:

- Of importance

$\bullet$ Of major importance

1. Caillard S, Chavarot N, Francois H, Matignon $\mathrm{M}^{\wedge} \#$, Greze C, Kamar N, et al. Is COVID-19 infection more severe in kidney transplant recipients? Am J Transplant. 2021;21(3):1295-303. https://doi.org/10.1111/ajt.16424.

2. Caillard S, Anglicheau D, Matignon M, Durrbach A, Greze C, Frimat L, et al. An initial report from the French SOT COVID Registry suggests high mortality due to COVID-19 in recipients of kidney transplants. Kidney Int. 2020;98(6):1549-58. https:// doi.org/10.1016/j.kint.2020.08.005.

3. Cravedi P, Mothi SS, Azzi Y, Haverly M, Farouk SS, Pérez-Sáez MJ, et al. COVID-19 and kidney transplantation: results from the TANGO International Transplant Consortium. Am J Transplant. 2020;20(11):3140-8. https://doi.org/10.1111/ajt.16185.

4. Azzi Y, Parides M, Alani O, Loarte-Campos P, Bartash R, Forest $\mathrm{S}$, et al. COVID-19 infection in kidney transplant recipients at the epicenter of pandemics. Kidney Int. 2020;98(6):1559-67. https://doi.org/10.1016/j.kint.2020.10.004.

5. Nair V, Jandovitz N, Hirsch JS, Abate M, Satapathy SK, Roth N, et al. An early experience on the effect of solid organ transplant status on hospitalized COVID-19 patients. Am J Transplant. 2021;21(7):2522-31. https://doi.org/10.1111/ajt.16460.

6. Raja MA, Mendoza MA, Villavicencio A, Anjan S, Reynolds JM, Kittipibul V, et al. COVID-19 in solid organ transplant recipients: a systematic review and meta-analysis of current literature. Transplant Rev (Orlando). 2021;35(1): 100588. https:// doi.org/10.1016/j.trre.2020.100588.

7. Moosavi SA, Mashhadiagha A, Motazedian N, Hashemazar A, Hoveidaei AH, Bolignano D. COVID-19 clinical manifestations and treatment strategies among solid-organ recipients: a systematic review of cases. Transpl Infect Dis. 2020;22(6): e13427. https://doi.org/10.1111/tid.13427.

8. Belsky JA, Tullius BP, Lamb MG, Sayegh R, Stanek JR, Auletta JJ. COVID-19 in immunocompromised patients: a systematic review of cancer, hematopoietic cell and solid organ transplant patients. J Infect. 2021;82(3):329-38. https://doi.org/10.1016/j. jinf.2021.01.022.

9. Ribas A, Sengupta R, Locke T, Zaidi SK, Campbell KM, Carethers JM, et al. Priority COVID-19 vaccination for patients with cancer while vaccine supply is limited. Cancer Discov. 2021;11(2):233-6. https://doi.org/10.1158/2159-8290. CD-20-1817.

10. Aydillo T, Gonzalez-Reiche AS, Aslam S, van de Guchte A, Khan Z, Obla A, et al. Shedding of viable SARS-CoV-2 after immunosuppressive therapy for cancer. N Engl J Med. 2020;383(26):2586-8. https://doi.org/10.1056/NEJMc2031670.

11. Avanzato VA, Matson MJ, Seifert SN, Pryce R, Williamson BN, Anzick SL, et al. Case study: prolonged infectious SARSCoV-2 shedding from an asymptomatic immunocompromised individual with cancer. Cell. 2020;183(7):1901-12.e9. https:// doi.org/10.1016/j.cell.2020.10.049.

12. Eckerle I, Rosenberger KD, Zwahlen M, Junghanss T. Serologic vaccination response after solid organ transplantation: a systematic review. PLoS ONE. 2013;8(2): e56974. https://doi.org/10. 1371/journal.pone.0056974.

13. Gangappa S, Kokko KE, Carlson LM, Gourley T, Newell KA, Pearson TC, et al. Immune responsiveness and protective immunity after transplantation. Transpl Int. 2008;21(4):293-303. https://doi.org/10.1111/j.1432-2277.2007.00631.x.

14. Serrano B, Bayas JM, Bruni L, Díez C. Solid organ transplantation and response to vaccination. Vaccine. 2007;25(42):7331-8. https://doi.org/10.1016/j.vaccine.2007.08.031.

15. Phadke VK, Scanlon N, Jordan SC, Rouphael NG. Immune responses to SARS-CoV-2 in solid organ transplant recipients. Curr Transplant Rep. 2021:1-13. doi: https://doi.org/10.1007/ s40472-021-00322-5.

16. Avery RK, Michaels M. Update on immunizations in solid organ transplant recipients: what clinicians need to know. Am J Transplant. 2008;8(1):9-14. https://doi.org/10.1111/j.1600-6143. 2007.02051.x.

17. Blumberg EA, Fitzpatrick J, Stutman PC, Hayden FG, Brozena SC. Safety of influenza vaccine in heart transplant recipients. J Heart Lung Transplant. 1998;17(11):1075-80.

18. Fischer ASL, Møller BK, Krag S, Jespersen B. Influenza virus vaccination and kidney graft rejection: causality or coincidence. Clin Kidney J. 2015;8(3):325-8. https://doi.org/10.1093/ckj/ sfv027.

19. Katerinis I, Hadaya K, Duquesnoy R, Ferrari-Lacraz S, Meier S, van Delden C, et al. De novo anti-HLA antibody after pandemic H1N1 and seasonal influenza immunization in kidney transplant recipients. Am J Transplant. 2011;11(8):1727-33. https://doi. org/10.1111/j.1600-6143.2011.03604.x.

20. Schaffer SA, Husain S, Delgado DH, Kavanaugh L, Ross HJ. Impact of adjuvanted H1N1 vaccine on cell-mediated rejection in heart transplant recipients. Am J Transplant. 2011;11(12):27514. https://doi.org/10.1111/j.1600-6143.2011.03743.x.

21. Fairhead T, Hendren E, Tinckam K, Rose C, Sherlock CH, Shi L, et al. Poor seroprotection but allosensitization after adjuvanted pandemic influenza $\mathrm{H} 1 \mathrm{~N} 1$ vaccine in kidney transplant recipients. Transpl Infect Dis. 2012;14(6):575-83. https://doi.org/10. 1111/tid.12006.

22. Xu Q, Sood P, Helmick D, Lomago JS, Tevar AD, Zeevi A. Positive flow cytometry crossmatch with discrepant antibody testing results following COVID-19 vaccination. Am J Transplant. 2021. https://doi.org/10.1111/ajt.16753.

23. Russo G, Lai Q, Poli L, Perrone MP, Gaeta A, Rossi M, et al. SARS-COV-2 vaccination with BNT162B2 in renal transplant patients: risk factors for impaired response and immunological implications. Clin Transplant. 2021:e14495. doi: https://doi.org/ 10.1111/ctr.14495.

24. Croce E, Hatz C, Jonker EF, Visser LG, Jaeger VK, Bühler S. Safety of live vaccinations on immunosuppressive therapy in patients with immune-mediated inflammatory diseases, solid organ transplantation or after bone-marrow transplantation - a systematic review of randomized trials, observational studies 
and case reports. Vaccine. 2017;35(9):1216-26. https://doi.org/ 10.1016/j.vaccine.2017.01.048

25. Candon S, Thervet E, Lebon P, Suberbielle C, Zuber J, Lima C, et al. Humoral and cellular immune responses after influenza vaccination in kidney transplant recipients. Am J Transplant. 2009;9(10):2346-54. https://doi.org/10.1111/j.1600-6143.2009. 02787.x.

26. Mulley WR, Dendle C, Ling JEH, Knight SR. Does vaccination in solid-organ transplant recipients result in adverse immunologic sequelae? A systematic review and meta-analysis. J Heart Lung Transplant. 2018;37(7):844-52. https://doi.org/10.1016/j. healun.2018.03.001.

27. Hurst FP, Lee JJ, Jindal RM, Agodoa LY, Abbott KC. Outcomes associated with influenza vaccination in the first year after kidney transplantation. Clin J Am Soc Nephrol. 2011;6(5):1192-7. https://doi.org/10.2215/CJN.05430610.

28. Scharpé J, Evenepoel P, Maes B, Bammens B, Claes K, Osterhaus $\mathrm{AD}$, et al. Influenza vaccination is efficacious and safe in renal transplant recipients. Am J Transplant. 2008;8(2):332-7. https://doi.org/10.1111/j.1600-6143.2007.02066.x.

29. Dos Santos G, Seifert HA, Bauchau V, Shinde V, Barbeau DM, Cohet C. Adjuvanted (AS03) A/H1N1 2009 pandemic influenza vaccines and solid organ transplant rejection: systematic signal evaluation and lessons learnt. Drug Saf. 2017;40(8):693-702. https://doi.org/10.1007/s40264-017-0532-3.

30. Ison MG, Blumberg E, Halasa N, Kaul D, Theodoropoulos NM, Wolfe CR. Antibodies, boosters, and optimizing SARS-CoV-2 vaccines for transplantation: a call for more research. Am J Transplant. 2021. https://doi.org/10.1111/ajt.16758.

31. Gee J, Marquez P, Su J, Calvert GM, Liu R, Myers T, et al. First month of COVID-19 vaccine safety monitoring - United States, December 14, 2020-January 13, 2021. MMWR Morb Mortal Wkly Rep. 2021;70(8):283-8. https://doi.org/10.15585/mmwr. mm7008e3.

32. Connors M, Graham BS, Lane HC, Fauci AS. SARS-CoV-2 Vaccines: much accomplished, much to learn. Ann Intern Med. 2021;174(5):687-90. https://doi.org/10.7326/M21-0111.

33. Krause PR, Fleming TR, Peto R, Longini IM, Figueroa JP, Sterne JAC, et al. Considerations in boosting COVID-19 vaccine immune responses. Lancet. 2021;398(10308):1377-80. https:// doi.org/10.1016/S0140-6736(21)02046-8.

34. Sattler A, Schrezenmeier E, Weber UA, Potekhin A, Bachmann F, Straub-Hohenbleicher H, et al. Impaired humoral and cellular immunity after SARS-CoV-2 BNT162b2 (tozinameran) primeboost vaccination in kidney transplant recipients. J Clin Invest. 2021;131(14). https://doi.org/10.1172/JCI150175. A comprehensive analysis of humoral and cellular responses in kidney transplant recipients after the second vaccination dose.

35. Bertrand D, Hamzaoui M, Lemée V, Lamulle J, Hanoy M, Laurent $\mathrm{C}$, et al. Antibody and $\mathrm{T}$ cell response to SARS-CoV-2 messenger RNA BNT162b2 vaccine in kidney transplant recipients and hemodialysis patients. J Am Soc Nephrol. 2021;32(9):214752. https://doi.org/10.1681/ASN.2021040480.

36. Stumpf J, Siepmann T, Lindner T, Karger C, Schwöbel J, Anders $\mathrm{L}$, et al. Humoral and cellular immunity to SARS-CoV-2 vaccination in renal transplant versus dialysis patients: a prospective, multicenter observational study using mRNA-1273 or BNT162b2 mRNA vaccine. Lancet Reg Health Eur. 2021;9.

37.• Prendecki M, Thomson T, Clarke CL, Martin P, Gleeson S, De Aguiar RC, et al. Immunological responses to SARS-CoV-2 vaccines in kidney transplant recipients. Lancet. 2021. https:// doi.org/10.1016/S0140-6736(21)02096-1. Analysis of immunological responses to two-dose vaccination with $\mathrm{BNT} 162 \mathrm{~b} 2$ (Pfizer-BioNTech) and ChAdOx1 (Oxford University-AstraZeneca) in kidney transplant recipients.
38. Rincon-Arevalo H, Choi M, Stefanski AL, Halleck F, Weber U, Szelinski F, et al. Impaired humoral immunity to SARS-CoV-2 BNT162b2 vaccine in kidney transplant recipients and dialysis patients. Sci Immunol. 2021;6(60). https://doi.org/10.1126/sciim munol.abj1031.

39. Cucchiari D, Egri N, Bodro M, Herrera S, Del Risco-Zevallos J, Casals-Urquiza J, et al. Cellular and humoral response after MRNA-1273 SARS-CoV-2 vaccine in kidney transplant recipients. Am J Transplant. 2021;21(8):2727-39. https://doi. org/10.1111/ajt.16701. A comprehensive study demonstrating reduced humoral and cellular response to SARS-CoV-2 vaccine in kidney transplant recipients.

40. Goldberg Y, Mandel M, Bar-On YM, Bodenheimer O, Freedman L, Haas EJ, et al. Waning immunity of the BNT162b2 vaccine: a nationwide study from Israel. medRxiv. 2021:2021.08.24.21262423. doi: https://doi.org/10.1101/2021. 08.24.21262423.

41. Bergwerk M, Gonen T, Lustig Y, Amit S, Lipsitch M, Cohen C, et al. Covid-19 Breakthrough infections in vaccinated health care workers. N Engl J Med. 2021;385(16):1474-84. https://doi.org/ 10.1056/NEJMoa2109072.

42. Wadei HM, Gonwa TA, Leoni JC, Shah SZ, Aslam N, Speicher LL. COVID-19 infection in solid organ transplant recipients after SARS-CoV-2 vaccination. Am J Transplant. 2021;21(10):34969. https://doi.org/10.1111/ajt.16618.

43.•• Qin CX, Moore LW, Anjan S, Rahamimov R, Sifri CD, Ali NM, et al. Risk of breakthrough SARS-CoV-2 infections in adult transplant recipients. transplantation. 2021. https://doi.org/10. 1097/TP.0000000000003907. An analysis of breakthrough SARS-CoV-2 infections in 18,215 fully vaccinated SOTRs at 17 transplant centers, compared to the general population.

44. Tau N, Yahav D, Schneider S, Rozen-Zvi B, Abu Sneineh M, Rahamimov R. Severe consequences of COVID-19 infection among vaccinated kidney transplant recipients. Am J Transplant. 2021;21(8):2910-2. https://doi.org/10.1111/ajt.16700.

45. Tsapepas D, Paget K, Mohan S, Cohen DJ, Husain SA. Clinically Significant COVID-19 following SARS-CoV-2 vaccination in kidney transplant recipients. Am J Kidney Dis. 2021;78(2):3147. https://doi.org/10.1053/j.ajkd.2021.05.004.

46. Malinis M, Cohen E, Azar MM. Effectiveness of SARS-CoV-2 vaccination in fully vaccinated solid organ transplant recipients. Am J Transplant. 2021;21(8):2916-8. https://doi.org/10.1111/ ajt.16713.

47. Mehta RB, Silveira FP. COVID-19 after two doses of mRNA vaccines in kidney transplant recipients. Am J Transplant. 2021. https://doi.org/10.1111/ajt.16778.

48. Anjan S, Natori Y, Fernandez Betances AA, Agritelley MS, Mattiazzi A, Arosemena L, et al. Breakthrough COVID-19 infections after mRNA vaccination in solid organ transplant recipients in Miami. Florida Transplantation. 2021;105(10):e139-41. https://doi.org/10.1097/TP.0000000000003902.

49. Aslam S, Adler E, Mekeel K, Little SJ. Clinical effectiveness of COVID-19 vaccination in solid organ transplant recipients. Transpl Infect Dis. 2021 Jul 29:e13705. https://doi.org/10.1111/ tid.13705.

50. https://www.cdc.gov/vaccines/acip/meetings/downloads/slides2021-08-13/02-COVID-Dooling-508.pdf (Accessed on August 14, 2021).

51. https://www.cdc.gov/vaccines/acip/meetings/downloads/slides2021-07/07-COVID-Oliver-508.pdf (Accessed on July 23, 2021).

52. Emergency Use Authorization (EUA) of the Pfizer-BioNTech COVID-19 Vaccine to Prevent Coronavirus. Fact sheet for healthcare providers administering vaccine. https://www.fda. gov/media/144413/download (Accessed on August 23, 2021). 
53. CDC COVID-19 vaccines for moderately to severely immunocompromised people. 19 Aug 2021.

54. COVID-19. A country-by-country guide to coronavirus vaccine booster plans. Aug 202021.

55. ECDC and EMA highlight considerations for additional and booster doses of COVID-19 vaccines. Sept 2021.

56. Public Health England, statement Sept 12021

57. Health Canada vaccination recommendation in special populations Aug 182021.

58. Hall VG, Ferreira VH, Ku T, Ierullo M, Majchrzak-Kita B, Chaparro C, et al. Randomized trial of a third dose of mRNA-1273 vaccine in transplant recipients. N Engl J Med. 2021;385(13):1244-6. https://doi.org/10.1056/nejmc2111462.

59.• Kamar N, Abravanel F, Marion O, Couat C, Izopet J, Del Bello A. Three doses of an mRNA Covid-19 vaccine in solid-organ transplant recipients. N Engl J Med. 2021;385(7):661-2. https:// doi.org/10.1056/NEJMc2108861. A report of the humoral response in a group of 101 SOTR who were given three doses of the messenger RNA vaccine BNT162b2.

60. Transplantation ISfHaL: SARS-CoV-2 Vaccination in heart and lung transplantation. Recommendations from the ISHLT COVID-19 Task Force. https://ishlt.org/ishlt/media/Documents/ COVID19_Vaccine-Recommendations_3-15-2021.pdf (2021). Accessed March 192021.

61. NIH. Special considerations in solid organ transplant, hematopoietic stem cell transplant, and cellular therapy candidates, donors, and recipients.

62. American Society of Transplantation COVID-19 Vaccination Guidance. http://www.myast.org/sites/default/files/AST-COVIDPtVaccine-3.18.21-final.pdf (Accessed on March 21, 2021).

63.• Grupper A, Katchman E, Ben-Yehoyada M, Rabinowich L, Schwartz D, Schwartz IF, et al. Kidney transplant recipients vaccinated before transplantation maintain superior humoral response to SARS-CoV-2 vaccine. Clin Transplant. 2021:e14478. doi: https://doi.org/10.1111/ctr.14478. A report of superior humoral response in a group of kidney recipients who were vaccinated before transplantation.

64. Klein SL, Pekosz A, Park HS, Ursin RL, Shapiro JR, Benner SE, et al. Sex, age, and hospitalization drive antibody responses in a COVID-19 convalescent plasma donor population. J Clin Invest. 2020;130(11):6141-50. https://doi.org/10.1172/JCI142004.

65. Jimenez M, Campillo NE, Canelles M. COVID-19 vaccine race: analysis of age-dependent immune responses against SARSCoV-2 indicates that more than just one strategy may be needed. Curr Med Chem. 2021;28(20):3964-79. https://doi.org/10.2174/ 0929867327666201027153123.

66. Bowman JS, Angstadt JD, Waymack JP, Jaffers GJ. A comparison of triple-therapy with double-therapy immunosuppression in cadaveric renal transplantation. Transplantation. 1992;53(3):556-9. https://doi.org/10.1097/00007890-19920 3000-00012.

67. Kubiet MA, Gonzalez-Rothi RJ, Cottey R, Bender BS. Serum antibody response to influenza vaccine in pulmonary patients receiving corticosteroids. Chest. 1996;110(2):367-70. https:// doi.org/10.1378/chest.110.2.367.

68. Herron A, Dettleff G, Hixon B, Brandwin L, Ortbals D, Hornick $R$, et al. Influenza vaccination in patients with rheumatic diseases. Safety and efficacy JAMA. 1979;242(1):53-6.

69. Spika JS, Halsey NA, Fish AJ, Lum GM, Lauer BA, Schiffman $G$, et al. Serum antibody response to pneumococcal vaccine in children with nephrotic syndrome. Pediatrics. 1982;69(2):219-23.

70. Friedman MA, Winthrop KL. Vaccines and disease-modifying antirheumatic drugs: practical implications for the rheumatologist. Rheum Dis Clin North Am. 2017;43(1):1-13. https://doi. org/10.1016/j.rdc.2016.09.003.
71. Cowan M, Chon WJ, Desai A, Andrews S, Bai Y, Veguilla V, et al. Impact of immunosuppression on recall immune responses to influenza vaccination in stable renal transplant recipients. Transplantation. 2014;97(8):846-53. https://doi.org/10.1097/ 01.TP.0000438024.10375.2d.

72. Jonker EFF, Uijlings MAC, Visser LG, Soonawala D. Comparison of the immunogenicity of Dukoral ${ }^{\circledR}$ oral cholera vaccine between renal transplant recipients on either a calcineurin inhibitor or mycophenolate - a controlled trial. Vaccine. 2019;37(23):3133-9. https://doi.org/10.1016/j.vaccine.2019. 04.010 .

73. Karbasi-Afshar R, Izadi M, Fazel M, Khedmat H. Response of transplant recipients to influenza vaccination based on type of immunosuppression: a meta-analysis. Saudi J Kidney Dis Transpl. 2015;26(5):877-83. https://doi.org/10.4103/1319-2442. 164556.

74. Grupper A, Rabinowich L, Schwartz D, Schwartz IF, BenYehoyada M, Shashar M, Katchman E, Halperin T, Turner D, Goykhman Y, Shibolet O, Levy S, Houri I, Baruch R, Katchman H. Reduced humoral response to mRNA SARS-CoV-2 BNT162b2 vaccine in kidney transplant recipients without prior exposure to the virus. Am J Transplant. 2021;21(8):2719-26. https://doi.org/10.1111/ajt.16615.

75. https://www.myast.org/sites/default/files/2021\%2005\% $2018 \%$ 20COVID19\%20VACCINE\%20FAQS-final\%20update.pdf (Accessed on July 01, 2021).

76. Carr EJ, Kronbichler A, Graham-Brown M, Abra G, Argyropoulos $\mathrm{C}$, Harper $\mathrm{L}$, et al. Review of early immune response to SARS-CoV-2 vaccination among patients with CKD. Kidney International Reports. 2021;6(9):2292-304. https://doi.org/10. 1016/j.ekir.2021.06.027.

77. Boyarsky BJ, Werbel WA, Avery RK, et al. Immunogenicity of a single dose of SARS-CoV-2 messenger RNA vaccine in solid organ transplant recipients. JAMA. 2021;325(17):1784-6. https://doi.org/10.1001/jama.2021.4385.

78.• Boyarsky BJ, Werbel WA, Avery RK, Tobian AAR, Massie AB, Segev DL, Garonzik-Wang JM. Antibody response to 2-dose SARS-CoV-2 mRNA vaccine series in solid organ transplant recipients. JAMA. 2021 Jun 1;325(21):2204-2206. https://doi. org/10.1001/jama.2021.7489. One of the first reports of the reduced humoral response among SOTR to messenger RNA SARS-CoV-2 vaccine.

79. Bruminhent J, Setthaudom C, Chaumdee P, Boongird S, Kiertiburanakul S, Malathum K, Nongnuch A, Phuphuakrat A, Jirasiritham S, Janphram C, Thotsiri S, Upama S, Assanatham M, Ramathibodi Transplant infectious diseases Rtid study group T. SARS-CoV-2-specific humoral and cell-mediated immune responses after immunization with inactivated COVID-19 vaccine in kidney transplant recipients (CVIM 1 Study). Am J Transplant. 2021 Oct 17. doi: https://doi.org/10.1111/ajt.16867.

80. Crespo M, Barrilado-Jackson A, Padilla E, Eguía J, EcheverriaEsnal D, Cao H, Faura A, Folgueiras M, Solà-Porta E, Pascual S, Barbosa F, Hurtado S, Ribera L, Río-No L, Pérez-Sáez MJ, Redondo-Pachón D, Pascual J; Mariscovid Research Group. Negative immune responses to two-dose mRNA COVID-19 vaccines in renal allograft recipients assessed with simple antibody and interferon gamma release assay cellular monitoring. Am J Transplant. 2021 Sep 22. doi: https://doi.org/10.1111/ajt.16854.

81. Guarino M, Cossiga V, Esposito I, Furno A, Morisco F. Effectiveness of SARS-CoV-2 vaccination in liver transplanted patients: the debate is open! J Hepatol. 2021;S01688278(21):01961-9. https://doi.org/10.1016/j.jhep.2021.07.034.

82. Hallett AM, Greenberg RS, Boyarsky BJ, Shah PD, Ou MT, Teles AT, Krach MR, López JI, Werbel WA, Avery RK, Bae S, Tobian AA, Massie AB, Higgins RSD, Garonzik-Wang JM, Segev DL, Bush EL. SARS-CoV-2 messenger RNA vaccine 
antibody response and reactogenicity in heart and lung transplant recipients. J Heart Lung Transplant. 2021;S10532498(21):02445-51. https://doi.org/10.1016/j.healun.2021.07. 026.

83. Itzhaki Ben Zadok O, Shaul AA, Ben-Avraham B, Yaari V, Ben Zvi H, Shostak Y, Pertzov B, Eliakim-Raz N, Abed G, Abuhazira M, Barac YD, Mats I, Kramer MR, Aravot D, Kornowski R, Ben-Gal T. Immunogenicity of the BNT162b2 mRNA vaccine in heart transplant recipients - a prospective cohort study.Eur J Heart Fail. 2021; 23(9):1555-1559.

84. Marion O, Del Bello A, Abravanel F, Couat C, Faguer S, Esposito L, Hebral AL, Izopet J, Kamar N. Safety and immunogenicity of anti-SARS-CoV-2 messenger RNA vaccines in recipients of solid organ transplants. Ann Intern Med. 2021;174(9):13361338. https://doi.org/10.7326/M21-1341. Assessment of the immune response among SOTR to messenger RNA SARSCoV-2 vaccine.

85. Masset C, Kerleau C, Garandeau C, Ville S, Cantarovich D, Hourmant M, Kervella D, Meurette A, Guillot-Gueguen C, Guihard I, Giral M, Dantal J, Blancho G. A third injection of the BNT162b2 mRNA COVID-19 vaccine in kidney transplant recipients improves the humoral immune response. Kidney Int. 2021 30;100(5):1132-5. https://doi.org/10.1016/j.kint.2021.08. 017. Assessment of the immune response among SOTR to messenger RNA SARS-CoV-2 vaccine.

86. Mazzola A, Todesco E, Drouin S, Hazan F, Marot S, Thabut D, Varnous S, Soulié C, Barrou B, Marcelin AG, Conti F. Poor antibody response after two doses of SARS-CoV-2 vaccine in transplant recipients. Clin Infect Dis. 2021 Jun 24:ciab580. https://doi.org/10.1093/cid/ciab580.

87. Peled Y, Ram E, Lavee J, Sternik L, Segev A, Wieder-Finesod A, Mandelboim M, Indenbaum V, Levy I, Raanani E, Lustig Y, Rahav G. BNT162b2 vaccination in heart transplant recipients: clinical experience and antibody response. J Heart Lung Transplant. 2021;40(8):759-62. https://doi.org/10.1016/j.healun.2021. 04.003.

88.• Prendecki M, Thomson T, Clarke CL, Martin P, Gleeson S, De Aguiar RC, Edwards H, Mortimer P, McIntyre S, Mokreri D, Cox A, Pickard G, Lightstone L, Thomas D, McAdoo SP, Kelleher P, Willicombe M; Imperial Renal COVID-19 vaccine study group in collaboration with the OCTAVE Study Consortium. Immunological responses to SARS-CoV-2 vaccines in kidney transplant recipients. Lancet. 2021 Oct 4:S0140-6736(21)02096-1. doi: https://doi.org/10.1016/S0140-6736(21)02096-1. A comprehensive assessment of the immune response to SARS-CoV-2 vaccine in kidney transplant recipients.

89. Rabinowich L, Grupper A, Baruch R, Ben-Yehoyada M, Halperin T, Turner D, Katchman E, Levi S, Houri I, Lubezky N, Shibolet O, Katchman H. Low immunogenicity to SARSCoV-2 vaccination among liver transplant recipients. J Hepatol. 2021;75(2):435-8.

90. Rashidi-Alavijeh J, Frey A, Passenberg M, Korth J, Zmudzinski J, Anastasiou OE, Saner FH, Jahn M, Lange CM, Willuweit K. Humoral Response to SARS-Cov-2 vaccination in liver transplant recipients - a single-center experience. Vaccines (Basel). 2021;9(7):738. https://doi.org/10.3390/vaccines9070738.

91. Rozen-Zvi B, Yahav D, Agur T, Zingerman B, Ben-Zvi H, Atamna A, Tau N, Mashraki T, Nesher E, Rahamimov R. Antibody response to SARS-CoV-2 mRNA vaccine among kidney transplant recipients: a prospective cohort study. Clin Microbiol Infect. 2021;27(8):1173.e1-1173.e4.

92. Shostak Y, Shafran N, Heching M, Rosengarten D, Shtraichman O, Shitenberg D, Amor SM, Yahav D, Ben Zvi H, Pertzov B, Kramer MR. Early humoral response among lung transplant recipients vaccinated with BNT162b2 vaccine. Lancet Respir Med. 2021;9(6):e52-3. https://doi.org/10.1016/S2213-2600(21) 00184-3.

93. Strauss AT, Hallett AM, Boyarsky BJ, Ou MT, Werbel WA, Avery RK, Tobian AAR, Massie AB, Hamilton JPA, GaronzikWang JM, Segev DL. Antibody response to severe acute respiratory syndrome-coronavirus-2 messenger RNA vaccines in liver transplant recipients. Liver Transpl. 2021 Aug 18:https://doi.org/ 10.1002/lt.26273. https://doi.org/10.1002/lt.26273.

94. Thuluvath PJ, Robarts P, Chauhan M. Analysis of antibody responses after COVID-19 vaccination in liver transplant recipients and those with chronic liver diseases. J Hepatol. 2021 Aug 26:S0168-8278(21)02002-X. https://doi.org/10.1016/j.jhep. 2021.08.008.

95. Benotmane I, Gautier G, Perrin P, Olagne J, Cognard N, FafiKremer S, Caillard S. Antibody response after a third dose of the mRNA-1273 SARS-CoV-2 vaccine in kidney transplant recipients with minimal serologic response to 2 doses. [Epub ahead of print ] JAMA 2021 Jul 23. doi: https://doi.org/10.1001/jama. 2021.12339.

96. Del Bello A, Abravanel F, Marion O, Couat C, Esposito L, Lavayssière L, Izopet J, Kamar N. Efficiency of a boost with a third dose of anti-SARS-CoV-2 messenger RNA-based vaccines in solid organ transplant recipients. Am J Transplant. 2021 Jul 31:https://doi.org/10.1111/ajt.16775. doi: https://doi.org/10. 1111/ajt.16775. A report of the response to the third dose of SARS-CoV-2 vaccine in SOTR.

97. Hall VG, Ferreira VH, Ku T, Ierullo M, Majchrzak-Kita B, Chaparro C, Selzner N, Schiff J, McDonald M, Tomlinson G, Kulasingam V, Kumar D, Humar A. Randomized trial of a third dose of mRNA-1273 vaccine in transplant recipients. N Engl J Med. 2021;385(13):1244-6. https://doi.org/10.1056/NEJMc 2111462.

98. Kamar N, Abravanel F, Marion O, Couat C, Izopet J, Del Bello A. Three doses of an mRNA Covid-19 vaccine in solid-organ transplant recipients. N Engl J Med. 2021 Aug 12;385(7):661662. doi: https://doi.org/10.1056/NEJMc2108861.

99. Stumpf J, Tonnus W, Paliege A, Rettig R, Steglich A, Gembardt F, Kessel F, Krooger H, Arndt P, Sradnick J, Frank K, Tonn T, Hugo C. Cellular and humoral immune responses after three doses of BNT162b2 mRNA SARS-Cov-2 vaccine in kidney transplant. Transplantation. 2021. https://doi.org/10.1097/TP. 0000000000003903.

100. Werbel WA, Boyarsky BJ, Ou MT, Massie AB, Tobian AAR, Garonzik-Wang JM, Segev DL. Safety and immunogenicity of a third dose of SARS-CoV-2 vaccine in solid organ transplant recipients: a case series. Ann Intern Med. 2021;174(9):1330-2. https://doi.org/10.7326/L21-0282.

101. Madan RP, Tan M, Fernandez-Sesma A, Moran TM, Emre $\mathrm{S}$, Campbell A, et al. A prospective, comparative study of the immune response to inactivated influenza vaccine in pediatric liver transplant recipients and their healthy siblings. Clin Infect Dis. 2008;46(5):712-8. https://doi.org/10.1086/527391.

102. Nailescu C, Xu X, Zhou H, Hall H, Wilson AC, Leiser JD, et al. Influenza vaccine after pediatric kidney transplant: a Midwest Pediatric Nephrology Consortium study. Pediatr Nephrol. 2011;26(3):459-67. https://doi.org/10.1007/s00467-010-1729-1.

Publisher's Note Springer Nature remains neutral with regard to jurisdictional claims in published maps and institutional affiliations. 